\title{
継時処理スキル:日本人英語学習者においてリス ニング成績上位群と下位群を分ける技能
}

\section{Information serial processing skill: Factors differentiating high performers and low performers of English listening in Japanese EFL learners}

\section{小山 義徳(おやま よしのり) 東京大学大学院教育学研究科 博士課程}

In recent years, factors affecting listening comprehension in second language settings have been discussed by many researchers. One of the important variables that affect comprehension is phoneme perception. A few researchers have tested phoneme identification training for foreign language learners to improve their English listening performance (e.g., Logan et al.,1991; Lively et al., 1994). Although these studies revealed the crucial role of the phoneme in listening at the input level, further investigation is needed to fully understand the mechanisms of English listening comprehension in foreign language learning.

To understand the information processing mechanisms in listening, the unique characteristics of listening comprehension cannot be ignored. In listening, auditory information flows almost continuously and listeners have to deal with serial and evanescent acoustic signals and process them in real time. The current study examined whether information serial processing skill is the key factor differentiating high performers and low performers in EFL listening.

Researchers de Bot, Paribakht and Wesche (1997) adapted Levelt's L1 speech production model and proposed a lexical comprehension and production model in L2. In the model, spoken or written signals were processed through a shared 
route to access lexemes, and lemma then reach the concept. Hirai (1999) also reported that the optimal listening rate and reading rate are similar. These studies suggest that the information processing mechanism in listening and reading comprehension are quite similar. Therefore, the present study presented visual stimuli to evaluate participants' information serial processing skills.

The study hypothesized that high performers in listening would have strong information serial processing skills and would be able to perform well in serial text presentation tasks. On the other hand, low performers in listening were presumed not to have developed information serial processing skills yet, and would not able to perform well in serial text presentation tasks, but perform well in non-serial presentation tasks such as normal reading tasks.

The subjects for this experiment were 21 native Japanese students (average age 21.1). All stimuli were presented by the stimulus presentation software "Super Lab 2.0." Two conversational English skits were used in each task, and a total of 10 skits were shown to a participant.

The experiment consisted of five tasks. In the Reading Task, an English skit was presented and participants were asked to read the passage and summarize it in Japanese. In the Listening Task, an English skit was played once on a CD player and participants were asked to listen to the skit and summarize it in Japanese. In the Self-Paced Task, participants were asked to press the "space" button of a desktop personal computer, and an English skit was displayed word by word. Participants were asked to summarize it in Japanese after they finished reading it. In the Slow Paced task, an English skit was displayed word by word. Each word was presented for $472 \mathrm{~ms}$. After all words in the skit were presented, participants were asked to summarize it in Japanese. In the Fast Paced task, an English skit was displayed word by word. Each word was shown for $363 \mathrm{~ms}$ and after all words in the skit were displayed, participants were asked to summarize the skit in Japanese. The summaries written by participants were graded by three language teachers from 0 (incorrect) to 5 (correct) on the Likert scale. Each task consisted of two passages, and the total points for each task was therefore 10.

The participants were divided by mean score of the listening task, and two groups, "High performers of listening (High)" and "Low performers of listening (Low)", were formed. Statistical comparison was made between these two listening groups in the Reading Task, Self-paced Task, Slow-paced Task, and Fast-paced Task.

In the Reading Task, in which non-serial information processing was allowed and the participants could read the text in a back and forth manner, both the High and the Low group performed well. However, in the Self-Paced, Slow and Fast Tasks, the Low group showed lower performance than the High group. Therefore, when serial processing was not required, the two groups understood the information at same level, but in the serial processing requiring tasks, the Low group performed worse than the High group. On the other hand, the High group showed a high performance in all tasks. This results indicates that serial informa- 
tion processing skill is a key factor in differentiating high performance and low performance in the listening skills of Japanese EFL learners.

英語のリスニングにおいて学習者が処理すべき情報は音声であり,すぐに消えてしまう.その ため, 学習者は入力されてくる情報を継時的に次々と処理していく能力が要求される. 本研究 は, リスニング能力が高い学習者は入力される情報を継時的に処理することができるが, リス ニング能力が低い学習者は入力情報を継時的に処理することが困難であるという仮説を立て 実験を行った。

その結果, 継時的な情報処理が要求される課題において, リスニング能力が低い学習者の 理解度が著しく下がることが明らかになった. 一方, リスニング能力が高い学習者の理解度 は, より速い継時的な情報処理が要求される課題においても落ちることはなかった. このこと から, 入力情報を次々と継時的に処理できる,「継時処理スキル」はリスニング能力と関連して いる可能性があることが明らかになった。

\section{はじめに}

英語を学習した人の中には, 耳で聞いた際には全く分からなかった英語を, 英文 として読んでみたらあまりにも簡単で愕然とした経験のある方がいる. なぜ一般的に リスニングはリーディングと比べて難しくなるのであろうか.

\section{リスニングの定義}

まず,リスニングとはどのような行為のことを指すのであろうか. 第二言語における リスニング研究のレビューを行ったRubin(1994)は, スピーチの速さや音のストレスな どの「テキスト要因」, 話し手の性別などの「対話者要因」, 質問の種類などの「夕ス ク要因」, 背景知識や記憶力などの「聞き手要因」, トップダウンやボトムアップに代 表される「プロセス要因」の5つの要因がリスニングの理解に影響しているとしてい る.

また, リスニングの能力を構成する3つのスキルとしてRost(1991)は, 音を聞き分 けたり, 単語を認識する「知覚スキル」と, 文法やプラグマティックな事柄を同定する 「分析スキル」, 自分の持っている背景知識と結びつける「統合スキル」をあげてい る.

しかし,リスニングは, 通信が発達した1940年代は,「メッセージの発信と再構 築」, コンピュータが発展した1950年代は, 「入力された情報を分析し貯蔵し効果 的に読み出す行為である」と定義されるなどリスニングがどのような行為を指すか は, 時代背景の影響を強く受けて変遷してきた歴史がある(Rost, 2002). そこで, 本 研究では, Rubin(1994)やRost(1991)の研究を踏まえた上で, 特に情報処理プロセス の面に焦点を当て,「リスニングとは情報を音素レベルや単語単位で正確に捉え, 文 法知識等を駆使して瞬時に処理し, 自分の背景知識と結びつけることで, そこに含 まれるメッセージを理解する認知処理である」と定義した上で, 研究を進める.

\section{外国語学習におけるリスニングとリーディングの関倸}

入力される情報が音声か文字かという違いがあるが, 外国語学習におけるリス二 ングとリーディングには似ている点が多くある. 長い間, この 2 つ技能は受身的な ものであると考えられてきた. しかし, O’ Malley \& Charmot (1990)がリーディングも 
リスニングも, 学習者が聞き取ったり読みとったりした内容と, 自分の持っている背 景知識と結びつけてそこに含まれるメッセージを理解しようとする能動的なプロセ スであると主張しているように，最近の研究ではリスニングとリーディングは，推測 やトップダウン・ボトムアップの双方向の処理を含む非常に能動的なスキルであると 考えられてきている.

また, リーディングとリスニングの情報処理プロセスには多くの共通があると, 情 報処理モデルの観点からも指摘されている. de Bot, Paribakht, \& Wesche (1997)は母 語におけるスピーチモデルを改変し, 外国語学習におけるリーディング・リスニング・ ライティング・スピーキングの 4 技能の語彙処理過程をモデル化した.このモデルに おいて,リーディングとリスニングは入力段階では情報は音声形式か文字形式かで異 なっているが, 情報が入力された後は, lexemes(例: 三人称単数現在形 “runs”, 過去 形“ran”など, 原型から派生した語)の処理が行われ, lemma(例：“run”など 語の 原型)が解析された後, 概念の理解に至るとしている. そして, これらのプロセスはリ スニングとリーディングの間で共有されている.

リーディングとリスニングの情報処理の共有仮説は実験データからも支持されて いる. Hirai(1999)は英語学習者にリーディングに適切な提示速度とリスニングに適切 な提示速度の関係を検討した結果, 両者はほぼ同じであったことを報告しており, 第 二言語の聴覚情報処理と視覚情報処理で, 共有されているプロセスが存在する可能 性があることを示唆している. このように, 第二言語の視覚情報と聴覚情報の情報 処理プロセスには共有部分が存在する可能性が先行研究から示唆されている. それ では, なぜ学習者にとつてリスニングはリーディングよりも難しくなってしまうのであ ろうか.

\section{外国語学習のリスニングを難しくしている主な要因}

竹蓋(1981)は日本語の音声体系が英語のリスニングに与える影響を検討し, 日本人 学習者は, 日本語ではあまり使用されない/r/-/1/, / / / / / / /などの音素の聞き取りが困難 であることを明らかにした. また, 語のストレスの位置の理解(Vanderplank, 1988)や, 英語固有のリズムの認知(Vanderplank, 1993)もリスニングを困難にしている要因とし て, これまでの研究ではあげられている.つまり, リスニングが困難になる要因の $1 つ$ として, 処理すべき情報が音声であるため, 入力情報を正確にとらえることが非常に 難しいということがあげられる.

次に挙げられるのが, スピーチの速度である. Griffith(1990)は毎分200語よりも速 いスピーチは, 中級と初級の間に位置した学習者の理解を妨げたことを明らかにして いる. また，スピーチの速度別に理解度を比較した研究(Griffith，1992)では，1分間 に188個の単語が話されるMedium条件や, 1分間に250個の単語が話されるFast条件 と比較して, スピーチ速度が最も遅く，1分間に127個の単語が話される速さのSlow 条件が, リスニングの理解度が高かったことを報告している.このように, スピーチの 速度はリスニング時の理解度に影響を及ぼすことが明らかになっている.

リスニングが困難になる原因として三つ目に挙げられるのが, 母語と目標言語の 統語構造の違いである. Glisan(1985)は母語の統語構造が目標言語のリスニング成 績に与える影響を報告している. 彼女は英語が母語であるアメリカ人を対象に, 3 種の スペイン語の統語構造がリスニングの理解度に与える影響を検討した. その結果, リ スニング課題となつたスペイン語の統語構造が, 実験参加者の母語である英語の統 語構造にも存在する条件ではリスニングの理解度が高かったが, 課題の統語構造が 
英語とは異なる条件では, リスニングの理解度が低くなつた. このことから, 母語と 目標言語の統語構造の違いが, リスニングの理解度に影響を与えることを報告してい る.

\section{本研究で検討する要因: 継時処理スキル}

これらの要因に加え, 外国語学習においてリスニングによる理解を難しくする要 因として本研究で検討するのは「情報の継時処理スキル」である. 文字として書かれ た情報を処理するリーディングと比較して, リスニングにおいて情報を担うのは音声 である. そのため, 読み戻りが許されるリーディングとは異なり, リスニングにおける 認知処理においては, 入力情報を目標言語の統語構造のまま継時的に処理すること が要求される.この入力情報を処理できるスキルの有無が, リス二ングの理解に影響 している可能性がある. これまでに, 継時的な情報処理プロセスとリーディングの関 係を検討した研究(松原, 1992)はあったが, 継時的に情報を処理するスキルがリス二 ングの理解度と関連があることを検討した研究はない. そこで, 本研究はリスニング の能力が高い学習者とリスニングの能力が低い学習者で, 情報を継時的に処理する スキルが異なるのか検討を行う.

\section{仮説}

リスニング課題における成績が上位に位置する学習者は, 音素を正確に聞き取れ ることに加え, 入力される情報を継時的に次々と処理することができるために, リス ニングの際に良く理解することができると思われる. そのため, 単語が次々に提示さ れ読み戻りができない課題においても高い成績を示すことが予想される. 一方, リス ニング課題における成績が下位に位置する学習者は, 例え音素の聞き取りが正確に できたとしても, 入力される情報を継時的に処理することが苦手であると考えられ る. そのため, 読み戻りが許されずに情報を継時的に処理することが求められる課題 では, 理解度が著しく落ちることが予想される.

\section{方法 \\ 実験参加者}

都内在住の大学生 13 名と大学院生 8 名 (女性 10 人・男性 11 人) が本研究に参加し た。実験参加者の平均年齢は21.1歳で、全員が日本の中学・高校で英語を学んでき ており、英語圈に暮らした経験のある者は含まれていない.

\section{手続き}

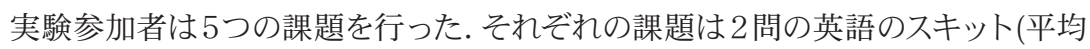
77.4 語)で構成されている(資料1). 条件の提示順序および各条件に使用した英文は 実験参加者間でカウンターバランスをとって提示された(表 1$)$. 課題の指示はすべて 実験用ソフトウェアSuperLab 2.0を用いてコンピューターの画面に提示された. 
表 1 課題の提示順序

\begin{tabular}{|c|c|c|c|c|c|}
\hline & LISTENING & READING & SELF & SLOW & FAST \\
\hline 被験者1 & スキットA,B & スキットC,D & スキットE,F & スキットG,H & スキットH,I \\
\hline 被験者2 & スキットH,I & スキットA,B & スキットC,D & スキットE,F & スキット $\mathrm{G}, \mathrm{H}$ \\
\hline 被験者3 & スキットG,H & スキットH,I & スキットA,B & スキットC,D & スキットE,F \\
\hline - & - & - & - & - & - \\
\hline - & - & - & - & - & - \\
\hline 被験者21 & - & - & - & - & - \\
\hline
\end{tabular}

課題

\section{LISTENING課題}

実験参加者は「これから音声が流れます.その後で聞き取った会話の概要を日本 語で書いてください. 制限時間はありません」という教示を読んだあとで, 音声を英検 の試験で行うのと同じ速さで1度聞き, その概要を書き出した.

\section{READING課題}

実験参加者は「画面に提示される英文を読んだ後で, 概要を日本語で書き出して ください. 制限時間はありません」という教示を読んだ後で, コンピューター画面に 全文が提示された英語のスキットを読み, その概要を書き出した.

SELF課題, SLOW課題, FAST課題において, 実験参加者は「これから英単語 が1語ごとに提示されます. その後で提示された内容の概要を日本語で可能なかぎ り書きだして下さい. 制限時間はありません」という教示を読んだ後で, 以下の事を 行った(図1).

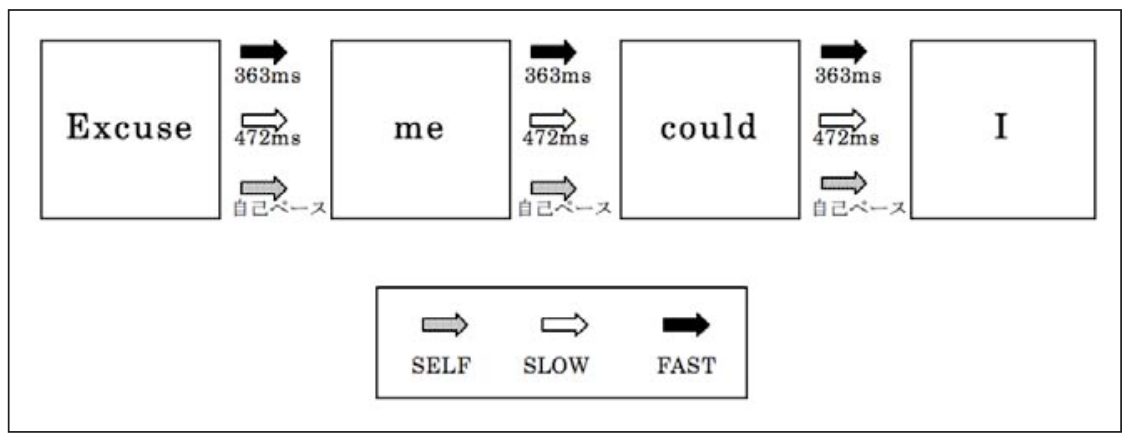

図1. 継時処理課題例(SELF課題, SLOW課題, FAST課題) 


\section{SELF課題}

スペースキーを押すごとに1単語ずつコンピューターの画面に提示される英語のス キットを, 自分のペースで1単語ずつ読んだ後で概要を書き出した.

\section{SLOW提示課題}

コンピューターの画面に自動的に 1 単語につき平均 $472 \mathrm{~ms}$ (ミリセカンド: $1 / 1000$ 秒)で提示される英語のスキットを読んだ後で概要を書き出した.

\section{FAST提示課題}

自動的にコンピューターの画面に1単語につき平均 $363 \mathrm{~ms} ゙$ 提示される英語のス キットを読んだ後で概要を書き出した。

SELF課題, SLOW課題, FAST課題の3つの課題は入力情報の継時的処理を測定 する課題である. 3 つ課題すべてにおいて実験参加者は英文を読み戻ることは許 されず, 提示された単語を英語の語順で読んでいかなければならない.

3 つの課題の違いは提示時間にある. SELF課題は自分のペースで単語ごとにスキ ットを読むことができる課題である. 一方, SLOW課題とFAST課題は単語は自動的 に一定時間提示され, 実験参加者は強制的にその提示速度(SLOW課題 $472 \mathrm{~ms} / 1$ 単 語, FAST課題362ms/1単語)でスキットを読むこととなる. 尚, 各課題の提示時間は Griffith(1992)に基づいて算出した.

実験後, 実験参加者には各課題で用いた英文のスクリプトを見せ, 知らない単語 が含まれていた場合にはその単語に丸をつけてもらい, 実験参加者の知らない単語 が課題の理解に影響していないか判断する際に用いた. 尚, 課題に用いたスキットは

「英検 2 級 リスニング問題ターゲット(旺文社, 2001)」を参考にした.

\section{採点方法}

リスニングの理解度を多肢選択型のテストで評定する方法は, 選択肢から内容の 予想が可能になるなど, 問題点が指摘されている(Wu, 1998). そのため, 本研究で は概要を日本語で書いてもらつたものを 3 名の語学教師によって評定するという方 法を採用した. 実験参加者が書き出した概要は, 0点(全く理解していない)から, 5 点 (大変良く理解している)の6段階で評定され, 各課題は5点 $\times 2$ 問 $=10$ 点満点で採点 された. また, 実験参加者が知らない単語に丸をつけたスクリプトの分析により, ス キットには分析対象となった実験参加者が知らない単語は含まれていないことが 確認された. 信頼係数として評定者間の相関 $(r)$ を算出したところ, 評定者間信頼性 係数(表 2)は高かつたため各課題の評定平均を理解度の指標として用いることとし た. LISTENING課題の評定結果を実験参加者のリスニング時の理解度の指標とし て使用した。 
表 2 評定者間信頼性

\begin{tabular}{lllc}
\hline & 評定者 1 & 評定者 2 & 評定者 3 \\
\hline 評定者 1 & 1 & & \\
\hline 評定者 2 & $0.84^{* *}$ & 1 & 1 \\
\hline 評定者 3 & $0.90^{* *}$ & $0.94^{* *}$ & $* * p<.01$ \\
\hline & & & 值は相関係数 $r$
\end{tabular}

\section{実験計画}

LISTENING 課題の成績が平均值 (3.24点)より高かった実験参加者を「リ スニング上位群」, 平均值よりもリスニング得点が低い実験参加者を「リス ニング下位群」とし，2 群 (リスニング上位・リスニング下位) $\times 4$ 提示条件 (READING, SELF, SLOW, FAST)の混合計画の分散分析を行った.

\section{結果}

英文全体が提示されるため読み戻りができ, 制限時間もないため, 本研究で用い た課題の中では最も容易であると考えれられたREADING課題において, 満点の50 $\%$ 以下の点数(5点以下)であった参加者 4 名は, 本研究の課題遂行に必要な英文理解 力を備えていないと判断し分析対象から除外した. その結果, 分析対象となつた実 験参加者は上位群10名, 下位群7名となった.リスニング熟達度(リスニング上位・リス ニング下位) $\times$ 課題(READING, SELF, SLOW, FAST)の混合計画の分散分析を行 った結果, リスニング熟達度の主効果 $(F(1,15)=41.60 p<.01)$, 課題の主効果 $(F(3,45)=$ $19.74, p<.01)$, 及びリスニング熟達度と課題の交互作用 $(F(3,45)=9.62, p<.01)$ が有意 であった(図 2 , 表 3$)$. 交互作用が有意であったので, リスニング熟達度ごとに単純主 効果の検定を行ったところ, リスニング上位群では統計的に有意な差はみられなか つたが $(F(3,27)=1.06$, n.s. $)$, リスニング下位群において統計的に有意な差がみられた $(F(3,18)=40.12, p<.01)$. TukeyのHSDによる多重比較を行ったところ, SLOW課題と FAST課題の間を除く,すべての課題間で5\%水準で統計的に有意な差がみられた. また, 課題ごとに単純主効果の検定を行ったところ, READING課題を除くすべての 課題において,リスニング上位群は下位群よりも高いスコアを示し, 統計的にも有意で あった(READING: $F(1,15)=3.64$, n.s., SELF: $F(1,15)=9.66$, $p<.01$., SLOW: $F(1,15)=$ 44.65, $p<.01 .$, FAST: $F(1,15)=31.68, p<.01)$.

\section{考察}

本研究は, 日本人が英語を学習する際にリーディングよりもリスニングが難しくな

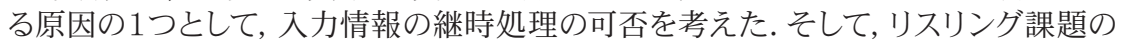
成績が上位に位置する学習者は, 入力情報を英語の語順のまま継時的に処理して理 解することができるが, リスリング課題の成績が下位に位置する学習者は, 入力情報 


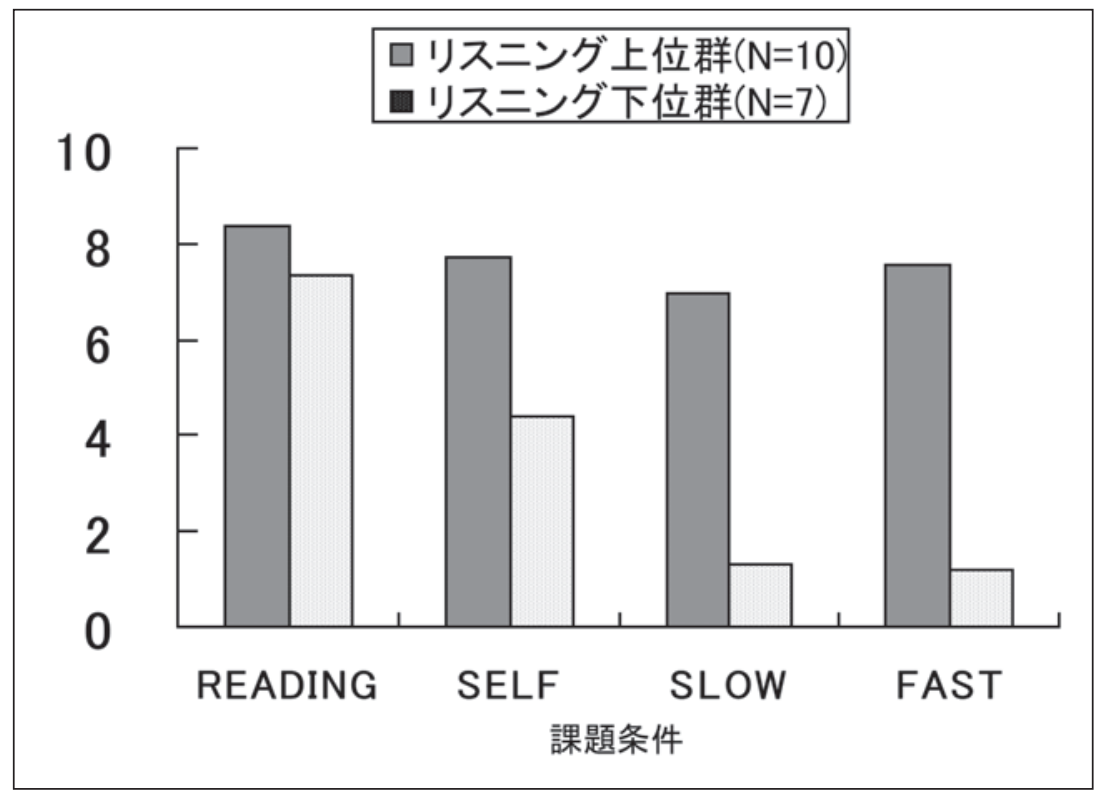

図2. 課題ごとの評定平均值

表 3 課題ごとの評定平均値

\begin{tabular}{lcccc}
\hline & READING & SELF & SLOW & FAST \\
\hline リスニング上位群 $(\mathrm{N}=10)$ & $8.37(0.97)$ & $7.70(2.20)$ & $6.97(2.06)$ & $7.53(2.93)$ \\
\hline リスニング下位群 $(\mathrm{N}=7)$ & $7.33(1.25)$ & $4.38(2.09)$ & $1.29(1.05)$ & $1.22(0.25)$ \\
\hline & & & $(\quad$ ) は標準偏差
\end{tabular}

を継時的に処理することが困難であるためリスニングの際に理解度が低下するとい う仮説を立て検討を行った.

その結果, 仮説は支持され, 英文に含まれる英単語が 1 単語ずつ自動的に提示 され, 情報の継時処理が要求されるSELF課題, SLOW課題及びFAST課題におい て,リスニング成績下位群の理解度が著しく下がることが明らかになった. しかし， 下位群のSLOW課題とFAST課題の成績に統計的に有意な差はなかったことから, 下位群の学習者にとつては1単語につき $472 \mathrm{~ms}$ 提示したSLOW条件の提示速度であ つても, 提示速度が速すぎた可能性がある. 課題の提示速度は先行研究(Griffith, 1992)に基づいて決定したが, 予備調査等を行い適切な提示速度を見極めた上 で, SLOW,FAST課題の提示速度を決定する必要があったと思われる. 一方, リスニ ング成績上位群は, 入力情報の継時処理が要求されるFAST, SLOW, SELF課題に 
おいて理解度が落ちることはなかった。このことから, 英語の語順で情報を瞬時に 処理できるスキルかあるかどうかが, リスニング時の理解度に影響している可能性が あることが明らかになった。

リスニング成績下位群においては, 読み戻りはできないが提示速度を自分で操作 できるSELF提示条件においても, READING課題よりも理解度が下がっていること から, 提示速度によらず読み戻りができないことが, リス二ングが苦手な学習者が 視覚情報を処理し理解する際の大きな障害になっている可能性がある. READING 課題においては両群で評定平均に統計的に有意な差はなかったことから, 読み戻り が許される条件下での両群の理解度は同等のレベルにあると考えられる.したがつ て, 本研究においてリスニング成績上位群とリスニング成績下位群の間にみられた FAST, SLOW, SELF課題の成績の違いは, 読み戻りをしないで英文を理解できるか どうかにあるともいえるだろう.

入力される情報が視覚情報か聴覚情報かという違いはあるが，これをリスニング の際の聴覚情報の処理場面で考えると, リスニング成績上位群の学習者は読み戻り をしなくても英文を理解できるスキルがあるから, リスニングの際にも次々と耳から 入力される聴覚情報を英語の語順のまま継時的に処理し理解することができるので はないだろうか. 一方, リスニング成績下位群の学習者は, 読み戻りをしないと英文 が理解できないため, 情報の継時的な処理が要求されるリスニングにおいて, 理解 度が大きく落ち込むのではないだろうか.

このことから, 「英語学習において, 文字で読むと簡単に分かる内容が, 音で聞く と難しくなるのはなぜか」という問いに対しては, 読んで理解する際には, 読み戻り をして情報を処理することが許されるが, 音で聞いて理解する際には, 音声情報を継 時的に処理ができなければならないということが，1つの原因としてあげられるだろ う.

\section{本研究の意義と今後の展望}

これまでの英語リスニング研究では, 単語の入力レベルに目を向けて, 聞き分けの 困難な音素や, 英語特有のストレスなどの要因によって, 単語を正確に聞き取れないこ とが, 英語のリスニングが難しくなる原因であると先行研究の多くは考えていた(e.g., Lively Pisoni, Yamada, Tohkura, \& Yamada, 1994 ; Logan, Lively, \& Pisoni, 1991). それ に対し, 本研究はリスニング成績が高い学習者と低い学習者を分けるひとつの要因と して, 情報の継時処理スキルが関与していることを示した. しかし, その場で処理しな ければすぐに消えてしまう音声の特性を考えても, 継時処理をしなければリス二ング の際にメッセージは理解できないと仮定することは自然であると思われる. ただ, 本 研究はリスニングの理解における音素要因を否定するものではない. 外国語のリス二 ングが理解できるためには, 学習者が音素の聞き取りができ, 音声情報の正確なイン プットがある程度できることが必要である。

\section{本研究の限界点}

入力されてくる情報を次々と継時的に処理できるスキルの有無が, リス二ング成績 上位群とリスニング下位群を分ける要因の1つであることを本研究は明らかにした。 しかし, リスニング成績が低い学習者がなぜ継時的に情報を処理できないのか, リス ニング成績が高い学習者がどのようにして継時処理スキルを獲得したのかについて 
は, 本研究のデザインからは明らかになっていない. そのため, 情報を継時的に処理 するスキルをつけるにはどのような介入が有効なのか検討を行い, 教室における英語 リスニング指導に活かすことが必要である.

\section{引用文献}

de Bot, K., Paribakht, T.S., \& Wesche, M.B. (1997). Toward a lexical processing model for the study of second language vocabulary acquisition: Evidence from ESL reading. Studies in Second Language Acquisition, 19, 309-329.

DeMauro. (1992). Examination of the relationship among TSE, TWE, \& TOEFL scores. Language Testing, 9, 149-161.

Glisan, E. W. (1985). The effect of word order on listening comprehension \& pattern retention - An experiment in Spanish as a foreign-language. Language Learning, 35, 443-472.

Griffiths, R.(1990). Speech rate and NNS comprehension: A preliminary study in time-benefit analysis. Language Learning, 40, 311-336.

Griffiths, R. (1992). Speech rate and listening comprehension: Further evidence of the relationship. TESOL Quarterly, 26, 385-390.

Hirai, A. (1999). The relationship between listening \& reading rates of Japanese EFL learners. Modern Language Journal, 83, 367-384.

Lively, S.E., Pisoni, D.B., Yamada, R.A., Tohkura, Y. \& Yamada, T. (1994). Training Japanese listeners to identify $/ \mathrm{r} /$ \& /1/: III.Long-term retention of new phonetic categories. Journal of the Acoustic Society of America, 96, 2076-2086.

Logan, J.S., Lively, S.E. \& Pisoni, D.B. (1991). Training Japanese listeners to identify /r/ \& /1/: A first report. Journal of the Acoustic Society of America, 89, 874-886.

松原賢一(1992)英文の継時的読解過程の分析と支援 東京工業大学大学院理工学 研究科修士論文.

旺文社 (2001) 英検 2 級リスニング問題ターゲット改訂新版. 東京: 旺文社.

O'Malley, J.M. \& Chamot, A.U. (1990), Learning Strategies in Second Language Acquisition. Cambridge: Cambridge University Press.

Rost, M.(1991). Listening in action. New York: Prentice Hall.

Rost, M.(2002). Teaching and Researching Listening. London: Longman.

Rubin, J. (1994). A review of 2nd-language listening comprehension research. Modern Language Journal, 78, 199-221.

竹蓋幸夫 (1981)。 日本人大学生の米語音聴取にみる'Acquired Similarity' と'Acquired Distinctiveness' 子音間距離知覚実験による観察. Language Laboratory, 18, 11-28.

Vanderplank, R. (1988). Implication of differences in native and nonnative speaker approaches to listening. British Journal of Language Teaching, 26, 32-41.

Vanderplank, R. (1993). Pacing and Spacing as predictors of difficulty in speaking and understanding English. ELT Journal, 47, 117-125. 
Wu, Y. (1998). What do tests of listening comprehension test? A retrospection study of EFL test-takers performing a multiple-choice task. Language Testing, $15,21-44$.

\section{資料1}

資料1＼cjkstart課題として用いた英文の例

Excuse me, could I ask you about this exercise? I don't know much about weight training.

Certainly. What is it you'd like to know?

Well, I've been doing it for a month, but I'm not getting any stronger.

Well, maybe you need to use heavier weights, or maybe you've been doing it incorrectly.

Why don't you show me how you do it? 


\section{Reviews}

\section{The Psychology of the Language Learner: Individual Differences in Second Language Acquisition. Zoltán Dörnyei. Mahwah, NJ: Lawrence Erlbaum Associates, 2005. $270 \mathrm{pp}$.}

Reviewed by

Greg Brakefield

Toho University

In Psychology of the Language Learner, Zoltán Dörnyei has set out to write the definitive single-authored book on Individual Differences (IDs), their complex relationship with SLA, and how they affect L2 proficiency. This is an ambitious book and, some might argue, a logical next step in Dörnyei's work, which has sought from early on to create a comprehensive and unified theory of motivation in SLA in which IDs play a leading role.

Admirers of Dörnyei will not likely be disappointed with this book, though it is something of a departure from previous works which focused almost exclusively on motivation: IDs, or those characteristics that differentiate people from each other and make individuals unique, are examined from the perspective of educational psychology and its relation to SLA. As usual, Dörnyei provides a comprehensive, balanced overview of the field-past, present, and future-of educational psychology and ID research in relation to applied linguistics, much of which will be new even to those who have read his previous works.

The book discusses the current state of affairs in the field of IDs research, which Dörnyei is cautiously optimistic about, and specifically focuses on ID variables (in Chapters 2 to 6) such as personality, temperament, mood, language aptitude, motivation, learning styles and strategies, and how those constructs are operationalized, assessed, and researched to advance the understanding of the complex mechanisms of SLA.

Throughout, Dörnyei makes the credible case that ID factors and research into them are far more important than the body of current research might indicate. He states that this is an area of research that is full of untapped potential to illuminate the understanding of the underlying 
processes of SLA, asserting, IDs have been found to be the most consistent predictors of L2 learning success (p. 2). (Also see Dörnyei \& Skehan, 2003; Sawyer \& Ranta, 2001.) The case for the importance of ID research, however, is tempered by Dörnyei's acknowledgement that understanding the complex mechanisms and underlying processes of IDs and their relation to L2 proficiency is a highly problematic and even philosophical quest somewhat akin to illuminating the meaning of human existence itself. This is something I often enjoy about Dörnyei's writing, because he is not afraid to step off the podium of "serious academia" and wax philosophic at appropriate moments, which adds a liveliness to the writing that is often missing in other works on the subject.

In addition to the great depth and breadth given to the theoretical in Chapters 2 to 4, Dörnyei delves into the practical, discussing in some detail in Chapters 5 and 6 the implications for practitioners in the field. This gives insight into how an understanding of ID mechanisms and processes can help (enable) teachers to understand, identify, and accommodate various learning styles and strategies. This is something that I found to be of great interest. As in much of his previous work, Dörnyei does a very serviceable job of painting in broad strokes when discussing the practical implications, but I would have preferred more specific information regarding how to practically implement various ID-related strategies in the classroom.

Dörnyei's final appraisal is that while there is a wealth of research in the field of IDs which is pointing the way, there is a great need to reexamine and refine to further understanding, saying that, "The future of L2 studies in general, lies in the integration of linguistic and psychological approaches in a balanced and complementary manner" (p. 219). This bold and ambitious statement belies the inherent difficulties of the endeavor, which Dörnyei acknowledges as daunting but necessary.

I found the book to be a readable, well-written, well-researched, and well-argued work that provides an excellent overview of the subject. That said, my mild disappointment with the book is that it does not give the reader what they are inevitably searching for-a unified and comprehensive theory which explains in clear detail the fundamental mechanisms and processes of the way people learn a second language vis-à-vis IDs and how teachers can apply that knowledge in the classroom. However, these are early days in this area and a unified theory will take years to emerge. In the meantime, this book will make for a good start and I would recommend it to anyone interested in IDs as they pertain to SLA. It is my 